•综述・

\title{
长江流域林木资源的重要性及种质资源保护
}

\author{
叶俊伟1,2 张云飞 2 王晓娟 2 蔡 $^{\text {荔 }}{ }^{2}$ 陈家宽 ${ }^{3 *}$ \\ 1 (中国科学院昆明植物研究所中国西南野生生物种质资源库, 昆明 650201) \\ 2 (上海科技馆上海自然博物馆自然史研究中心, 上海 200127) \\ 3 (复旦大学生物多样性科学研究所, 上海 200438)
}

摘要: 中国长江流域有着丰富的林木资源, 包含极高水平的物种多样性、特有性和遗传多样性。根据考古证据, 在 旧石器和新石器时代长江文明早期的孕育与发展中, 林木在食物、能源、工具、建筑和舟船中的应用起到了关键 作用。现在, 长江流域和珠江流域逐渐成为国内木材供给的热点地区。面对木材供给总量不足和大径级木材结构 性短缺问题, 长江流域林木资源将是未来国内木材安全的重要保障。这使得林木种质资源的保护更加迫切。针对 长江流域林木种质资源保护存在的家底不清和保存体系不完善问题, 我们应尽快完成林木种质资源的全面调查和 重要树种的多样性分析; 完善原地、异地和设施保存相结合的保存体系。

关键词: 长江流域; 林木种质资源; 长江文明; 木材安全; 保存体系

\section{The significance of forest resources and the conservation of germplasm resources in the Yangtze River Basin}

\author{
Junwei Ye ${ }^{1,2}$, Yunfei Zhang ${ }^{2}$, Xiaojuan Wang ${ }^{2}$, Li Cai ${ }^{2}$, Jiakuan Chen ${ }^{3 *}$ \\ 1 Germplasm Bank of Wild Species in Southwest China, Kunming Institute of Botany, Chinese Academy of Sciences, \\ Kunming 650201 \\ 2 Natural History Research Center for Shanghai Natural History Museum, Shanghai Science \& Technology Museum, \\ Shanghai 200127 \\ 3 Institute of Biodiversity Science, Fudan University, Shanghai 200438
}

\begin{abstract}
The Yangtze River Basin in China has abundant forest resources, including high species diversity, endemism, and genetic diversity. According to archaeological evidence, forest resources played a substantial role during the formation and development of Yangtze River Civilization in the Paleolithic and Neolithic Age. Food, energy, tools, architecture, and boats were all derived from forest resources. At present, the Yangtze River Basin and Pearl River Basin have become the domestic center of wood supply in China. Faced with insufficient timber supply and shortages of large diameter timber, responsible management of the Yangtze River Basin forest resources is crucial to guarantee domestic timber security in the future. Understanding the status of remaining resources and creating an improved preservation system are needed to effectively conserve forest germplasm resources in the Yangtze River Basin. A comprehensive investigation of forest germplasm resources and diversity analyses of important tree species and a preservation system that is composed of in situ, ex situ and vitro preservation is urgently needed.
\end{abstract}

Key words: Yangtze River Basin; forest germplasm resource; Yangtze River civilization; wood security; preservation system

长江流域因其独特的自然地理特征和自然资 源资本, 不仅是中华文明重要的起源地之一, 也是 我国目前资源最丰富、经济最集中的巨型产业带(李
琴和陈家宽, 2017)。依托长江流域黄金水道, 我国 提出了长江经济带发展战略, 该战略以“生态优先, 绿色发展; 共抓大保护, 不搞大开发”为总要求, 将

收稿日期: 2017-10-18; 接受日期: 2018-02-28

基金项目: 国家自然科学基金(31600301)

* 通讯作者 Author for correspondence. E-mail: jkchen@fudan.edu.cn 
生态环境保护摆在了首要位置。林木资源负载了高 水平的物种多样性和遗传多样性, 有经济、生态、 社会、文化等多重重要功能, 在生态系统稳定性维 持、生态环境保护及社会经济发展中极其重要。长 江流域因复杂的地质活动和气候变化历史及多样 的地形环境条件, 形成了丰富的林木资源(Qiu et al, 2011; 应俊生和陈梦玲, 2011)。

本文将从林木资源在长江文明早期孕育与发 展以及国内木材安全中的重要性出发, 揭示林木种 质资源保护的紧迫性，并针对保护工作中仍存在的 问题，提出相应的对策与建议。

\section{长江流域林木资源现状}

长江流域总面积为 18,000 万ha (图1), 占中国陆 地总面积的 $18.8 \%$ 。该流域主要位于亚热带常绿阔 叶林区，并包括青藏高原植被区的一部分(吴征镒 等, 2011)。全流域森林面积11,000万ha, 占全国森林 总面积的 $56.5 \%$, 森林覆盖率为 $29.2 \%$ 。因复杂的地 质活动和气候变化历史及多样的地形和环境条件, 该流域形成了丰富的林木资源(Qiu et al, 2011; 应 俊生和陈梦玲, 2011), 包含高水平的物种多样性和 特有性。在中国种子植物物种多样性最高的 3 个热 点地区中, 有 2 个位于长江流域, 分别是横断山脉 地区和华中地区，各有种子植物7,954种和6,390种, 分别占全国总数的 $28 \%$ 和 $22 \%$ 左右; 各有中国特有 植物 5,079 种和 4,035 种, 分别占该地区种子植物总 数的63.9\%和63.1\% (应俊生和陈梦玲, 2011)。长江 流域分布有珍稀濒危植物 154 种, 占全国总数的 $39.7 \%$, 有国家重点保护植物 126 种, 占全国总数的 $42.9 \%$ (李红清等, 2008)。在华中和华南地区的20个 中国特有植物分布中心中，长江流域有 10 个, 并包 含了特有性最高的 3 个 (图 1, López-Pujol et al, 2011)。长江流域的用材树种同样丰富, 根据《中国 植物志》(http://frps.eflora.cn/jingji/6/), 中国有用材 树种1,100余种, 该流域有约540种, 占全国用材树 种总数的 $49 \%$ 左右。

长江流域的林木物种在多样的生境中经过长 时间的演化, 在不同区域内产生了显著差异, 形成 丰富的种内遗传多样性。首先, 与华北和东北地区 相比, 长江流域林木物种的种群内和区域内的遗传 多样性更高(Qiu et al, 2011), 说明该流域内的林木 遗传资源更丰富。其次, 对杉木(Cunninghamia lanceolata)、马尾松 (Pinus massoniana)、檫木 (Sassafras tzumu) 等重要造林树种的种源试验研究 发现, 很多树种都有显著的地理变异, 主要表现在 形态特征、生长量、适应性和木材性质等方面(顾万 春, 2001)。如杉木的物候期和耐寒性等与纬度呈明 显的负相关，生长和抗逆性与气候生态条件相关， 且以纬向变异为主(顾万春, 2001)。最后，该流域不 同区域间的遗传成分也往往明显不同，有多条普遍 存在的遗传间断(叶俊伟等, 2017)。如在杉木的12个 地理种源中，广东、广西、湖南、贵州和江西的共6 个聚为一类, 福建、浙江、湖北和安徽的共 4 个聚为 一类, 四川和陕西的 2 个聚为一类(陈由强和叶冰莹, 2001)。

\section{2 长江流域林木资源与长江文明早期发展}

人类文明形态的进化史也是人与自然互动关 系的发展史。人类早期文明发端于两河流域、尼罗 河流域、印度河流域及长江与黄河流域，只有中华 文明发源于湿润森林植被区(陈家宽和李琴, 2014)。 因此, 长江文明早期的孕育与发展离不开森林提供 的各种资源。在旧石器时代，林木在能源、食物、 工具和住处等方面影响了人类的生存。在新石器时 代，林木在建筑和舟船等中的应用为人类定居和文 化交流等创造了条件。

\section{1 旧石器时代}

在旧石器时代, 林木与人类的紧密联系体现在 能源、食物、工具和住处等方面。对植物果实、茎 叶和块根等的采集是该时期长江流域人类食物的 重要来源(熊大桐，1995)。在满足工具产生的3个充 分必要条件(动力、能力和智力)后，林木最先被人类 用来制作工具(罗建举，2015)。“构木为巢”、“钻木 取火”、“民不知衣服，夏多积薪，冬则炀之”等说法 表明了林木在人类住处和能源方面的应用。从考古 证据看, 旧石器时代的木制工具和木巢结构已几乎 无从考究，用火遗迹也䬥胗无几，目前仅有两处(熊 大桐, 1995)。在距今 170 万年前的云南元谋县遗址中, 发现了大量与哺乳动物化石伴生的炭屑以及两块 黑色的骨头，经鉴定可能是被烧过的，均是用火的 痕迹; 在距今 50-40万年前的安徽和县遗址中, 也 同样发现了火烧的骨头和灰烬(熊大桐, 1995)。

\section{2 新石器时代}

在距今约一万年前, 中国进入新石器时代。在 


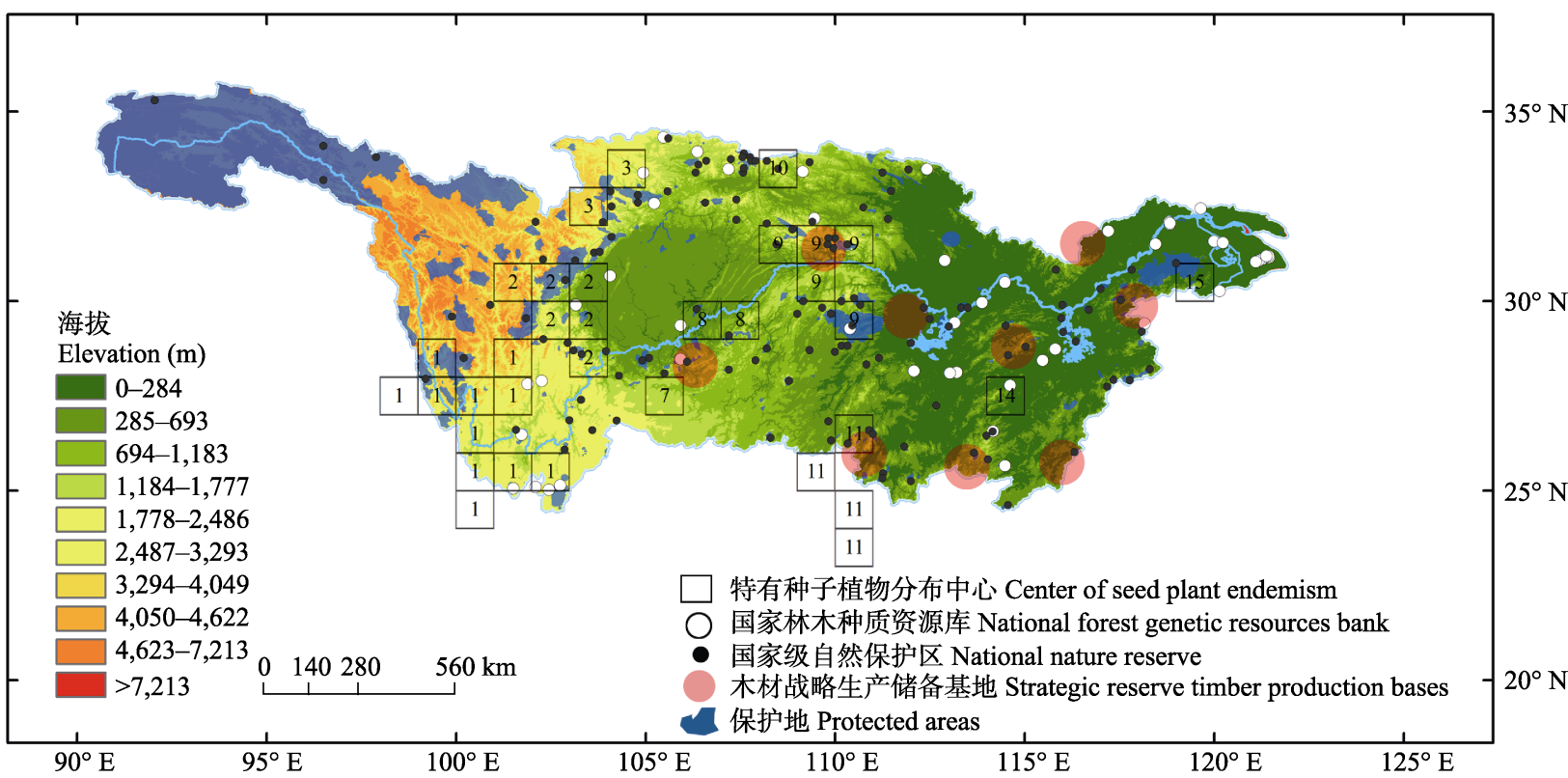

图1 长江流域的保护地(蓝色区域)、国家级自然保护区(黑点)、国家林木种质资源库(白点)、木材战略生产储备基地(红色区 域) 和特有种子植物分布中心 (黑色方框)。保护地数据来源于 WDPA (World Database on Protected Areas, https://www.protectedplanet.net/)。特有种子植物分布中心数据来自López-Pujol等(2011), 方框中的数字表示按特有性高低排 序的特有中心。

Fig. 1 Protected areas (blue region), national nature reserve (black point), national forest genetic resources bank (white point), strategic reserve timber production bases (red region) and center of seed plant endemism (black square) in Yangtze River Basin. Data of protected areas from WDPA (World Database on Protected Areas, https://www.protectedplanet.net/). Data of center of seed plant endemism from López-Pujol et al (2011), number in the square indicates the endemic center in sequence of level of plant endemism.

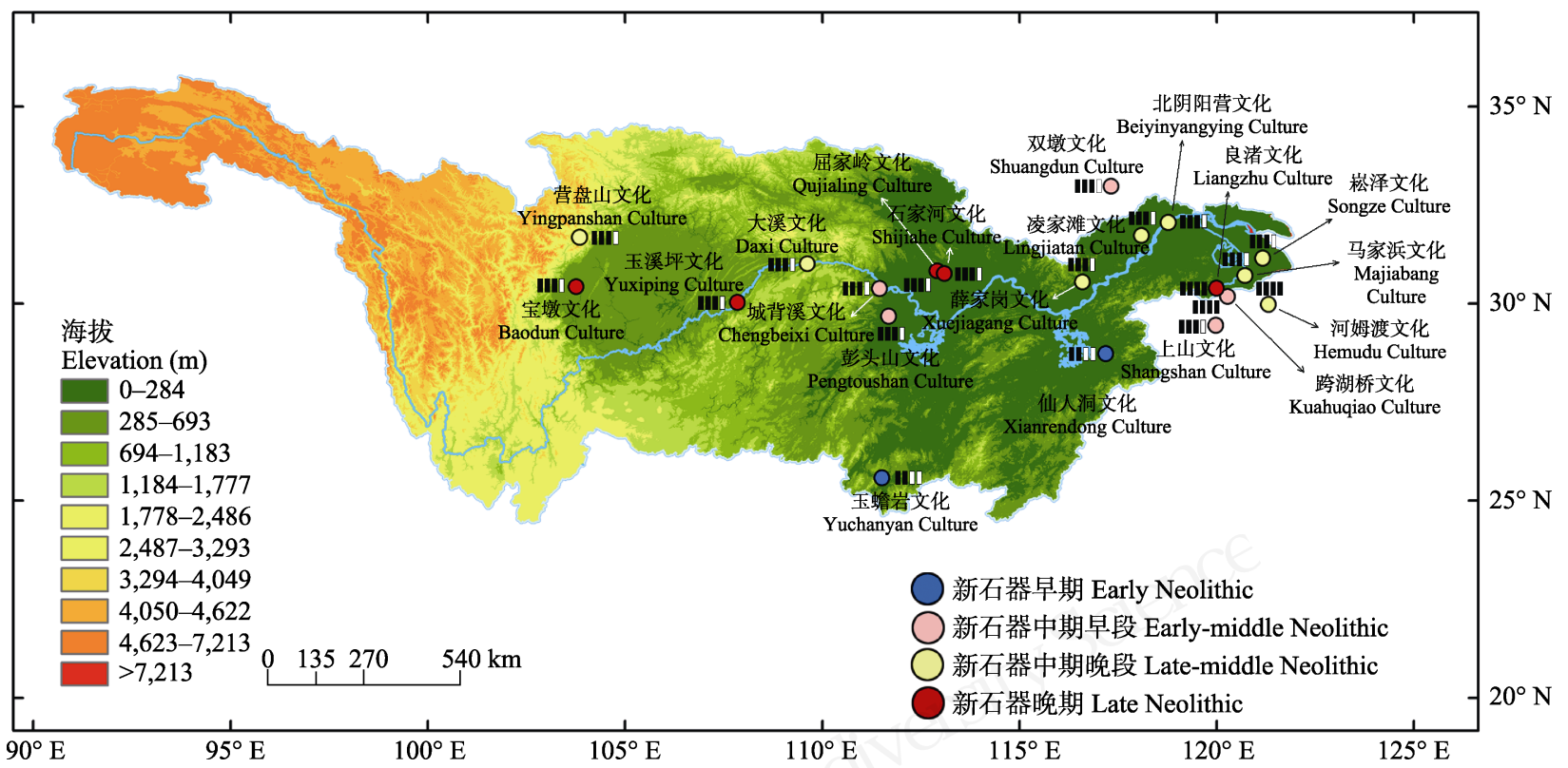

图2 不同时期长江文明对林木的利用方式。黑色方框从左至右分别表示林木在能源、工具，建筑和独木舟中的应用，白色表 示无此应用。新石器早期: 12,000-9,000年前; 新时期中期早段: 9,000-7,000年前; 新石器中期晚段: 7,000-5,000年前; 新石器 晚期: 5,000-4,000年前。

Fig. 2 Wood utilizations of Yangtze River Civilization in different phases. From left to right, the black square indicates wood utilizations in energy, tools, architecture and boat, white indicate no such utilization. Early Neolithic, 1,2000-9,000 BP; Early-middle Neolithic, 9,000-7,000 BP; Late-middle Neolithic, 7,000-5,000 BP; Late Neolithic, 5,000-4,000 BP. 
长江流域上、中和下游分别形成了多样且相对独立 的文化, 不同时期主要的文化几乎可以连成一个系 统而完整的过程(李琴和陈家宽, 2017)。该流域主要 的文化包括上游的营盘山、宝墩文化，中游的玉蟾 岩、城背溪、屈家岭文化, 以及下游的跨湖桥、良 渚、河姆渡文化等(图2)。新石器时代磨制石器的出 现使长江流域人类对林木的利用方式更加广泛(熊 大桐, 1995), 主要表现在能源、工具、建筑和舟船 中(图2)。

在新石器初期约一万年前的玉蟾岩和仙人洞 遗址中, 已有大量陶器出土, 表明人类已完全掌握 了火的使用, 反映了林木在能源方面的重要性。从 新石器时代长江文明遗址出土的核桃(Juglans sp.)、 雉栗(Castanea sp.)等果实遗存看, 采集仍是该时期 长江流域人类主要的食物获取方式。

新石器时代木制工具的应用较旧石器时代更 为多样化。新石器时代初期出土的穿孔石器很可能 是与木结合使用, 表明林木是生产工具的重要组成 部分。最早的木制工具在新石器中期早段(距今约 9,000-7,000年)的跨湖桥和彭头山文化遗址中发现, 少量的木制工具涵盖了生产、渔猎和纺织等功能。 最为多样化的木制工具在新石器中期晚段(距今约 7,000-5,000年)出现, 在河姆渡和钱山漾文化遗址 中发现了木柄、木杵、木矛、木刀、木铲和木碗等 大量生产和生活工具。除木器外, 新石器晚期(距今 约5,000-4,000年)的良渚文化遗址中还出土了 200 多 件竹编器物, 包括笴、竹席、管、篮、箩和簸箕等, 所用的竹䉝多数经过磨光, 与现代工艺已相差无几 (林华东, 1998)。

农耕文明的发展是长江流域人类结束频繁迁 移得以定居的前提, 木构建筑的出现和发展为定居 创造了条件, 村落开始形成( 邓先瑞和吴宜进, 2003)。在新石器中期早段的上山、跨湖桥和彭头山 等文化遗址中, 在房屋建筑遗迹均发现了 “柱洞” 结 构, 可能为木骨泥墙建筑的遗迹, 即在房基周围立 木柱, 通过捆绑编制的竹片或竹竿作为骨架, 或直 接用烧制土块构筑, 内外再涂抹草拌泥而成的建 筑。在新石器中期晚段, 长江流域文明遗迹的数量 和面积均有显著增加(朱诚等, 2015), 可能与木构建 筑的发展有关, 因为在长江流域不同地区均发现了 木骨泥墙建筑的遗迹(图2)。与此同时, 为适应江南 地区潮湿多雨的自然环境, 河姆渡文化还创造性地
用木材建造干栏式建筑，使用木材为主要材料。在 新石器晚期, 木构建筑进一步发展。如在良渚文化 遗址中, 不仅出现了大跨度屋顶，内设柱子或重檐， 加设回廊的房屋, 还发现了木构的水井、窝藏、礼 仪和祭祀等建筑(林华东, 1998)。

人类的定居离不开水，除饮用外，交通也是必 要的条件。舟船的发明和使用扩大了渔猎范围和活 动空间。利用木材可漂浮的特性, 人类最早的水上 交通工具为筏，随后将木材挖空而成的独木舟可增 大浮力、提高载重。从考古学看, 新石器时代火和 石斧的出现使人能够制造独木舟。在新石器时代中 期和晚期的跨湖桥、河姆渡、良渚文化遗址中均有 木桨出土，从侧面反映了舟船的使用(图2)。跨湖桥 文化遗址还出土了现存最早的独木舟, 其中舟体最 大的是整棵马尾松火烧锱㓣而成，长达 $5.6 \mathrm{~m}$ 。舟船 对生产、交换及文化的传播与交流也至关重要。如 江苏南京与广州飞我岭青山岗出土了相同的印纹 硬陶，渤海湾长岛遗址也出土了浙江河姆渡的陶釜; 有段石锱作为浙江新石器时代文明的代表艺术品, 在太平洋诸岛甚至美洲都有发现，表明长江流域的 文明可能通过舟船在国内外广泛传播。

在新石器时代后, 林木对自然科学及人文科学 等的发展也做出了巨大的贡献(罗建举, 2015)。值得 一提的是，随着木构建筑的发展，许多宫殿、寺庙 和民居都采用木材制作梁、架、檩、柱、斗拱、雀 替等构件并用榫卯结合。其灵活的风格、合理的布 局、适宜的建筑体量及精巧的装修在世界享有盛誉, 是5个最古老的建筑体系之一。

\section{3 长江流域林木资源与国内木材安}

\section{1 国内木材产业发展历史}

自新中国成立以来，国内木材产业的发展经历 了四个阶段(间振，2014)。第一是木材生产为主阶 段。林业在打破经济封锁、保障和支援国家经济建 设方面发挥了重要作用。东北国有林场是木材的主 要供给来源, 进口原木比例约为5\%（图3)。第二是 生态恢复过渡阶段。自20世纪70年代开始，三北防 护林工程和太行山绿化工程等重点林业工程建设 相继启动, 为保障木材供给, 国家在1984年实施了 一亿亩速生丰产林基地建设，使得木材来源开始向 用材林转移。在此阶段, 进口原木的比例有小幅度 提高(图3b)。此时南方用材林以中幼龄林为主，林分 
生产力低, 很大比例的木材依然由东北国有林场提 供。第三是生态建设为主发展阶段。以1998年天然 林保护工程、退耕还林还草工程的启动为标志, 国 家加强了对天然林采伐的限制，木材产量大幅缩减， 国内木材供给总量不足和大径级木材结构性短缺 问题开始显现，进口原木比例急速攀升(图3)。从 2000年开始，木材生产重心逐渐向南方的长江流域 和珠江流域各省份转移(杨超等, 2017), 用材林在木 材供给中的占比也越来越高(国家林业局, 2014)。第 四是木材战略储备阶段。以2012年全国木材战略储 备基地的启动为标志，国家林业局积极推进生态林 业和民生林业建设, 在确保生态安全的前提下, 把 木材安全提升到战略高度。这一时期, 国内木材需 求快速增长, 木材总量不足和大径级木材结构性短 缺问题更加突出。

目前, 国内木材需求越来越大, 木材进口仍持 续攀升(图3b)。自2016年起, 我国对天然林实施全面 保护，意味着国内每年从天然林获取的 5,000 万 $\mathrm{m}^{3}$ 左右木材必然向用材林转移。随着世界主要木材生
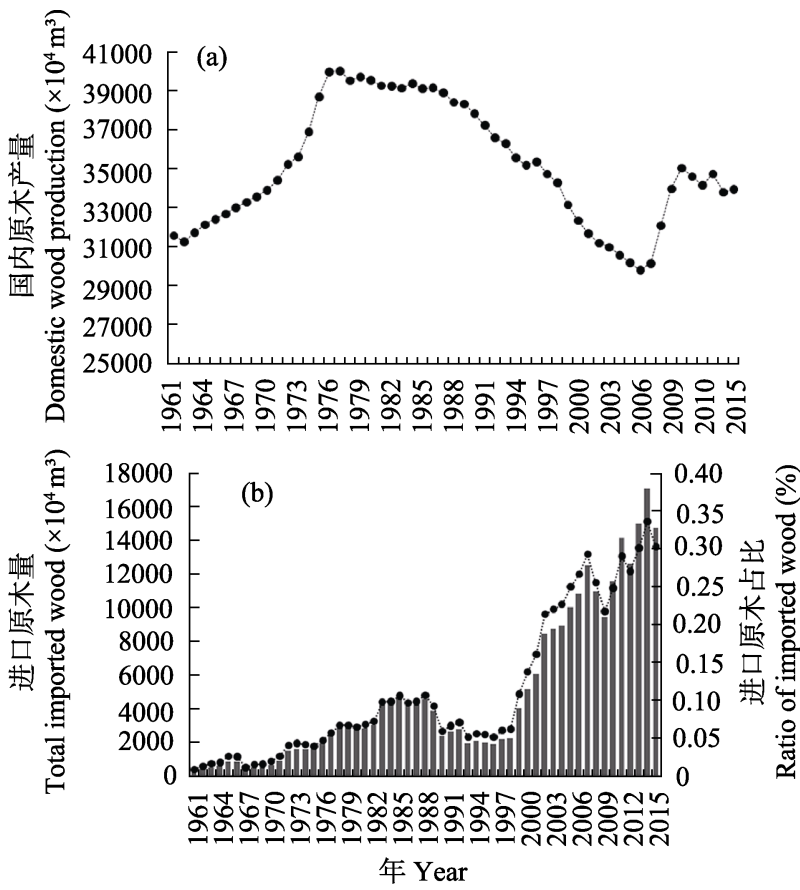

图3 1961-2015年国内原木产量(a)和原木进口量及其在消 耗量中占的比例 (b)。数据来自联合国粮食及农业组织 (FAO)。

Fig. 3 The domestic round wood production (a), imported round wood and its ratio in total consumption (b) in 1961-2015. Data from Food and Agriculture Organization of United Nations (FAO).
产国对木材出口的限制和国际生态环境保护压力 的增加，我国木材安全形势将日益严峻。同时，仅 杉木、杨树(Populus spp.)、桉树(Eucalyptus spp.)、 松树(Pinus spp.)四类就分别占到全国用材林总面 积、总蓄积的63\%和69\% (国家林业局, 2014)。结构 功能单一的速生丰产林不仅不能提供大径级木材, 还带来了一系列的生态问题，诸如生物多样性丧 失、水土流失、地力衰退和病虫害加剧等(刘世荣等, 2018)。因此，在保障国内木材安全的同时，必须做 好生态环境保护工作。

\section{2 长江流域在国内木材产业中的地位}

现在，长江流域在国内木材产业中的重要性已 初显。在2013年，南方地区7个省(云南、贵州、湖 南、江西、广东、广西和海南)已成为国内木材生产 的热点地区，主要位于长江流域和珠江流域(杨超 等, 2017)。在2015年, 国内木材已几乎全靠用材林 提供(约占93\%), 而长江流域木材产量占全国总量 的 $20 \%$ 左右，用材林面积和蓄积量占全国总量的 25\%左右(国家林业局, 2015)。在2015年的国家储备 林基地建设中, 主要位于长江流域的湖南、四川、 江西、湖北、重庆和贵州省份的珍稀树种营造林面 积占全国总量的54\%左右(国家林业局, 2015)。

在未来木材产业的战略中，长江流域将更重 要。《全国木材战略储备生产基地建设规划 (2013-2020年)》(以下简称《规划》) 规划了18片木 材战略储备基地，是保护国内珍稀树种种质资源和 初步缓解国内木材供需矛盾的强有力保障。长江流 域中下游有 9 个木材战略储备基地，数量占全国总 数的 $1 / 2$, 面积占总面积的 $40 \%$ 左右, 是木材战略储 备基地的集中区(图1)。在对各省市综合发展潜力进 行分析后，同样得到以江苏、江西、浙江、湖南为 核心的长江流域中下游地区是速生丰产林发展的 重点区域，此外，重点区域还包括长江流域内以四 川、云南为核心的西南地区，预计分别可提供木材 7,377 万和 2,981 万 $\mathrm{m}^{3}$ ，约占目前国内木材消耗量的 18\% (李红勋和马花如, 2013)。因此，长江流域是保 护林木资源, 缓解木材供需矛盾的重要区域。

针对我国珍贵用材几乎全依靠进口的形势, 《规划》明确指出在大力建设速生丰产林的同时, 还需大力建设珍稀大径级用材林。长江流域天然林 植被群落以樟科、壳斗科和木兰科等为优势科(王希 华，2006)，丰富的珍贵树种资源为珍稀大径级用材 
林建设提供了有利条件。通过木材色泽和密度等5 个指标的笁选, 李志辉等(2012)在长江流域共篎选 出 136 个珍贵用材树种, 占该流域用材树种总数的 25\%左右。在国家林业局发布的《中国主要栽培珍 贵树种参考名录(2017年版)》中(http://www.forestry. gov.cn/portal/main/s/4502/content-1045252.html/), 长 江流域分布的珍贵树种有 102 种, 占全国总数的 $53.1 \%$ 。优良乡土珍贵用材树种抗逆性较强, 生态功 能强, 不存在外来物种生态安全问题。选择长江流 域优良珍贵用材树种, 通过营造和发展用材林, 尤 其是根据近自然林业理论对结构功能单一的速生 丰产林的改造，在提供大量珍贵用材资源的同时， 也可显著提升生态功能, 缓解或解决速生丰产纯林 带来的生态问题。

\section{4 长江流域林木种质资源的保护}

种质资源是指种及种下分类单位遗传物质的 总称。对林木种质资源进行科学合理的保护和利用, 不仅在保障国内木材安全，还在保障农林业生产可 持续发展和促进生态稳定等方面具有重要意义(李 斌等, 2014)。鉴于长江流域林木资源在国内木材安 全和生态环境保护中有极其重要的地位, 且林木遗 传多样性下降引起的危害大、持续时间长、难以恢 复，使得长江流域的林木种质资源亟待充分保护。

\section{1 存在的问题}

(1)资源本底不清。林木种质资源的全面调查是 制定保存与评价利用策略的重要基础与前提。我国 已完成11个省(区 市)的林木种质资源调查工作, 在 长江流域, 完成调查的包括湖南、湖北、江西、重 庆和贵阳5省(市)(安元强等, 2016)。其中树种最多的 是湖北，共2,443种，占全国总数的27\%左右; 珍稀 濒危树种最多的是重庆，其次是湖北。其他省(区、 市)林木种质资源尚不清楚, 尤其是物种多样性和 特有性极高的云南、四川和贵州省。同时, 在调查 的过程中, 没有严格按照《林木种质资源调查技术 规程》, 还存在调查方法不统一、标准不统一、细 致程度不一致等问题, 难以进行全国范围林木种质 资源的统计与共享。

对林木种内多样性的评价同样贵乏。在全国主 要利用树种或具有环境、社会价值的约 260 余个树 种中, 仅对 80 个开展了遗传变异调查, 其中鹅掌楸 (Liriodendron Chinese)、珙桐(Davidia involucrata)、
黄山松(Pinus taiwanensis)等40余种植物可分布至长 江流域(郑勇奇, 2014)。在已分析的树种中，也往往 没有全面完成对形态、生长、材性、适应性以及种 内遗传多样性的评价。

(2)保存体系不完善。林木种质资源的保存包括 原地、异地和设施保存3种方式, 国内主要是前两种, 设施保存明显缺乏。原地保存方式的两个最主要方 面是建立自然保护区和森林公园。2012年时，长江 流域有林木种质资源保存功能的(除草原草甸、地质 遗迹和古生物遗迹类型外)不同级别自然保护区891 个，总面积为 3,863 万ha，占流域总面积的 $21.46 \%$, 其中国家级的 108 个，占流域保护区面积的 $65.5 \%$ (图1)。2016年时，该流域有国家级森林公园322个, 总面积 289.8 万ha，占流域总面积的 $1.7 \%$ 。保护区和 森林公园主要的保护对象为生态系统和国家重点 保护动植物物种等, 对林木种质资源保护的针对性 不强, 多为被动保护。仅在陕西太白山、江西井冈 山等少量保护区建立了原地保存林。在异地保存方 面，保存库的建设主要依据行政区和气候带。国家 林木种质资源平台建立了 8 个综合库，保存林面积 超200 ha, 重点保存了长江流域红锥(Castanopsis hystrix)、杜仲 (Eucommia ulmoides)、青檀(Pteroceltis tatarinowii) 等 60 余种超过 30,000 份种质 (郑勇奇, 2014); 国家林业局先后建立了国家林木种质资源 库99处, 其中长江流域有34处(图1), 包含了有重要 价值的马尾松、杉木、油茶(Camellia oleifera)、杪 椤(Alsophila spinulosa)等的专项库。异地保存库的 数量和针对性仍有待提高。在设施保存中, 国内没 有国家级林木种质资源低温保存库，仅部分省区 和机构建立了小规模的低温保存库，设施水平相 对落后。

\section{2 保护对策}

(1)全面调查资源本底。应尽快开展全面林木种 质资源调查，摸清家底。在调查基础规程的基础上， 进一步制定样地设置、信息描述、数据汇总与处理 等方面的标准。在做好调查技术方法、数据填写和 数据处理等方面的人员培训后，应尽快开展并完成 全国31个省(区、市)的林木种质资源家底调查与编 目汇总，尤其应首先完成长江流域生物多样性极其 丰富的云南、四川和贵州等区域的调查。还应利用 好种质资源调查信息管理系统，实现国家、省、市、 县四级林木种质资源信息管理系统实物与信息的 
统一与共享，与国家林木种质资源平台(http://www. nfgrp.cn/)对接, 实现全国数据的汇集和分析处理、 林木种质资源的开放共享。

在全面调查林木树种种类与自然分布区的同 时, 对有重要科研与应用价值的林木, 应全面展开 形态、适应性和遗传结构的地理变异、生物学特性 以及起源与迁移历史等的研究，掌握其变异规律。 进一步地, 通过遗传连锁图谱构建、数量性状位点 分析或目标性状与相关基因位点间的相关性，定位 生长发育、品质形成、环境适应性等重要性状的功 能基因, 了解其变化规律。通过对多样性的充分评 价, 可使收集和保存的群体或个体能真正代表林木 的遗传多样性, 加速林木物种尤其是大径级珍贵树 种的林木育种工作。

(2)完善保存体系。应尽快完善原地、异地和设 施保存相结合的林木种质资源保存体系。在原地保 存中, 应针对特有、珍稀、濒危和其他重要林木树 种，充分利用保护区、森林公园和其他保护地条件, 进一步设置原地保存林, 开展以维护遗传多样性为 目的的原地保存管理。在异地保存中, 需进一步增 设针对长江流域有极其重要价值树种的国家林木 种质资源专项库，如银杏(Ginkgo biloba)、鹅掌楸和 猕猴桃(Actinidia spp.)等; 除了依据行政区和气候 带外, 还应以植物区系、植被区划和林木育种区划 为基础，在不同区域，尤其是长江流域林木物种多 样性和特有性高的西南和华中地区及 9 处木材战略 储备基地，进一步增设国家林木种质资源库或综合 库, 加强林木种质的收集、保存与研究。此外, 由 于设施保存的种质有保存时间长、不易丢失、便于 交换和利用的优点(Li \& Pritchard, 2009), 应尽早规 划并建立国家林木种质资源设施保存库。

针对原地、异地和设施保存3种不同的保存方 式, 也应建立完整的监测与预警体系, 不定期地对 种子、个体、林分等保存材料进行抽样，对多样性 减少、活力丧失、遭受危险等情况及时进行预报预 警, 以便开展种群恢复、林木种质材料补充等工作, 保证林木种质资源的长期有效保存。

致谢: 感谢上海科技馆王小明馆长和南昌大学李琴 助理研究员在文章撰写和修改中提出的重要建议 与意见。

\section{参考文献}

An YQ, Zheng YQ, Zeng PY, Li B, Lin FR, Li WY (2016) Inventory of forest germplasm resources and its strategies. World Forestry Research, 29(2), 76-81. (in Chinese with English abstract) [安元强, 郑勇奇, 曾鹏宇, 李斌, 林富 荣，李文英 (2016) 我国林木种质资源调查现状与策略 研究. 世界林业研究, 29(2), 76-81.]

Chen JK, Li Q (2014) Ecological Civilization: The Inevitable Choice of Human History Development. Chongqing Publishing Group, Chongqing. (in Chinese) [陈家宽, 李琴 (2014) 生态文明: 人类历史发展的必然选择. 重庆出版 社, 重庆.]

Chen YQ, Ye BY (2001) Analysis of genetic relationship among Chinese fir (Cunninghamia lanceolata Hook) provenances by RAPD. Applied and Environmental Biology, 7(2), 130-133. (in Chinese with English abstract) [陈由 强, 叶冰莹 (2001) 杉木地理种源遗传变异的RAPD分析. 应用与环境生物学报, 7(2), 130-133.]

Deng XR, Wu YJ (2003) The formation and development of settlements in the Yangtze River Valley. Journal of China University of Geoscience (Social Sciences Edition), 3(6), 50-54. (in Chinese with English abstract) [邓先瑞, 吴宜进 (2003) 长江流域住区的形成与发展. 中国地质大学学报 (社会科学版), 3(6), 50-54.]

Gu WC (2001) China Planting: Forestry. China Agricultural Science and Technology Press, Beijing. (in Chinese) [顾万 春 (2001) 中国种植业大观·林业卷. 中国农业科技出版 社, 北京.]

Li B, Zheng YQ, Lin FR, Li WY (2014) The state of utilization and sustainable management of forest genetic resources of China. Journal of Plant Genetic Resources, 15, 1390-1394. (in Chinese with English abstract) [李斌, 郑勇奇, 林富荣, 李文英 (2014) 中国林木种质资源利用与可持续经营状 况. 植物遗传资源学报, 15, 1390-1394.]

Li DZ, Pritchard HW (2009) The science and economics of ex situ plant conservation. Trends in Plant Science, 14, 614-621.

Li HQ, Li YX, Lei AL, Lei MJ, Ma XJ (2008) A review of rare and endangered, and state key protected plants in the Yangtze River Basin. Yangtze River, 39(8), 17-24. (in Chinese) [李红清, 李迎喜, 雷阿林, 雷明军, 马晓洁 (2008) 长江 流域珍稀濒危和国家重点保护植物综述。人民长江, 39(8), 17-24.]

Li HX, Ma HR (2013) A Study on the Development Potential of Fast-Growing and High-Yielding Plantation in China. China Forestry Publishing House, Beijing. (in Chinese) [李 红勋, 马花如 (2013) 我国速生丰产用材林发展潜力研 究. 中国林业出版社, 北京.]

Li Q, Chen JK (2017) Theoretical thinking of the Great Yangtze River Protection: Natural capital, tracing civilization and protection countermeasures of the Yangtze River Basin. Science, 69(2), 29-32. (in Chinese) [李琴, 陈家宽 (2017) 
长江大保护的理论思考: 长江流域的自然资本、文明溯源 及保护对策. 科学, 69(2), 29-32.]

Li ZH, Li BH, Qi CJ, Yu XL, Wu Y (2012) Studies on importance of valuable wood species resources and its development strategy. Journal of Central South University of Forestry and Technology, 32(11), 1-8. (in Chinese with English abstract) [李志辉, 李柏海, 祁承经, 喻勋林, 吴毅 (2012) 我国南方珍贵用材树种资源的重要性及其发展策略. 中 南林业科技大学学报, 32(11), 1-8.]

Lin HD (1998) Study of Liangzhu Culture. Zhejiang Education Publishing House, Zhejiang. (in Chinese) [林华东 (1998) 良渚文化研究. 浙江教育出版社, 浙江.]

Liu SR, Yang YJ, Wang H (2018) Development strategy and management countermeasures of planted forests in China: Transforming from timber-centered single objective management towards multi-purpose management for enhancing quality and benefits of ecosystem services. Acta Ecologica Sinica, 38, 1-10. (in Chinese with English abstract) [刘世 荣, 杨予静, 王晖 (2018) 中国人工林经营发展战略与对 策: 从追求木材产量的单一目标经营转向提升生态系统 服务质量和效益的多目标经营. 生态学报, 38, 1-10.]

López-Pujol J, Zhang FM, Sun HQ, Ying TS, Ge S (2011) Centres of plant endemism in China: Places for survival or for speciation? Journal of Biogeography, 38, 1267-1280.

Luo JJ (2015) Wood and Human Civilization. Science Press, Beijing. (in Chinese) [罗建举 (2015) 木与人类文明. 科学 出版社, 北京.]

Qiu YX, Fu CX, Comes HP (2011) Plant molecular phylogeography in China and adjacent regions: Tracing the genetic imprints of Quaternary climate and environmental change in the world's most diverse temperate flora. Molecular Phylogenetics and Evolution, 59, 225-244.

State Forestry Administration (2014) The results of the Eighth National Forest Resource Inventory. Forest Resources Management, (1), 1-2. (in Chinese) [国家林业局 (2014) 第八次全国森林资源清查结果. 林业资源管理, (1), 1-2.]

State Forestry Administration (2015) China Forestry Statistical Yearbook. China Forestry Publishing House, Beijing. (in Chinese) [国家林业局 (2015) 中国林业统计年鉴. 中国 林业出版社, 北京.]

Wang XH (2006) The Phytogeography and Species Diversity of Typical Evergreen Broad-leaved Forest in China. PhD dissertation, East China Normal University, Shanghai. (in Chinese with English abstract) [王希华 (2006) 中国典型
常绿阔叶林植物地理与物种多样性研究. 博士学位论文, 华东师范大学, 上海.]

Xiong DT (1995) A History of Forest Science and Technology in China. China Forestry Publishing House, Beijing. (in Chinese) [熊大桐 (1995) 中国林业科学技术史. 中国林 业出版社, 北京.]

Wu ZY, Sun H, Zhou ZK, Li DZ, Peng H (2011) Floristics of Seed Plants from China. Science Press, Beijing. (in Chinese) [吴征镒, 孙航, 周浙昆, 李德铢, 彭华 (2011) 中国种子 植物区系地理. 科学出版社, 北京.]

Yan Z (2014) Development mode innovation, protecting the wood security: Constructions of wood strategic reserve bases with Chinese characteristics. (in Chinese) [闯振 (2014) 创 新发展模式, 保障木材安全: 建设具有中国特色的木材 战略储备基地.] http://www.forestry.gov.cn/portal/sfb/s/4379/ content-710923.html/. (accessed on 2017-06-15)

Yang C, Cheng BD, Xie Y, Song WM (2017) Development stage and spatiotemporal evolution of China's timber industry. Journal of Natural Resources, 32, 235-244. (in Chinese with English abstract) [杨超, 程宝栋, 谢屹, 宋维明 (2017) 中国木材产业发展的阶段识别及时空分异特征. 自然资源学报, 32, 235-244.]

Ye JW, Zhang Y, Wang XJ (2017) Phylogeographic breaks and the mechanisms of their formation in the Sino-Japanese floristic region. Chinese Journal of Plant Ecology, 41, 1003-1019. (in Chinese with English abstract) [叶俊伟, 张 阳, 王晓娟 (2017) 中国-日本植物区系中的谱系地理隔 离及其形成机制. 植物生态学报, 41, 1003-1019.]

Ying TS, Chen ML (2011) Plant Geography of China. Shanghai Scientific and Technical Publishers, Shanghai. (in Chinese) [应俊生, 陈梦玲 (2011) 中国植物地理. 上海科学 技术出版社, 上海.]

Zheng YQ (2014) The State of Forest Genetic Resources in China. China Agticulture Press, Beijing. (in Chinese) [郑勇 奇 (2014) 中国林木种质资源状况报告. 中国农业出版 社, 北京.]

Zhu C, Zheng CG, Wu L (2015) Environmental Archaeology Since the Neolithic Age in the Yangzte River Valley, China. Science Press, Beijing. (in Chinese) [ 朱诚, 郑朝贵, 吴立 (2015) 长江流域新石器时代以来环境考古. 科学出版社, 北京.]

(责任编委：蔵润国 责任编辑：黄祥忠) 